\title{
Root Distribution and Mineral Uptake of Coarse-rooted Trees Grown in Cupric Hydroxide-treated Containers
}

\author{
Michael A. Arnold \\ School of Agriculture, Tennessee Technological University, Box 5034, \\ Cookeville, TN 38505
}

\author{
Daniel K. Struve ${ }^{2}$ \\ Department of Horticulture, The Ohio State University, Columbus, \\ OH 43210-1096
}

Additional index words. Quercus acutissima, sawtooth oak, Quercus alba, white oak, Quercus falcata var. pagodifolia, cherrybark oak, Quercus stellata, post oak, Juglans nigra, black walnut, Carya glabra, pignut hickory, Carya illinoinensis, pecan, Castanea mollissima, Chinese chestnut, Taxodium distichum, common baldcypress, root morphology, container production, copper, macronutrients, micronutrients

\begin{abstract}
Seedlings of nine coarse-rooted species-sawtooth oak (Quercus acutissima Carruth), white oak (Q. alba $\mathbf{L}$.), cherrybark oak (Q. falcata var. pagodifolia Elliott), post oak (Q. stellata Wangenh.), black walnut (Juglans nigra L.), pignut hickory [Carya glabra (Mill.) Sweet], pecan [C. illinoinensis (Wangenh.) C. Koch], Chinese chestnut (Castanea mollissima Blume), and common baldcypress [Taxodium distichum (L.) L. Rich]-were grown for one growing season in nontreated containers or in containers treated on their interior surfaces with white interior latex paint containing $100 \mathrm{~g} \mathrm{Cu}(\mathrm{OH})_{2}$ /liter. Seedlings of each species and container treatment were harvested twice: once after being transplanted from 3.2- to 15.0-liter containers and at the end of the growing season. Cupric hydroxide-treated containers decreased the amount of circled, kinked, and matted roots formed at the container wall-medium interface in all species tested. Plants grown in $\mathrm{Cu}(\mathrm{OH})_{2}$-treated containers also had altered root dry-weight partitioning. The partitioning patterns were species specific and included $6 \%$ to $20 \%$ increases in the percentage of root dry weight in interior vs. exterior portions of the rootball (white oak, black walnut, Chinese chestnut, and baldcypress), $10 \%$ to $21 \%$ increases in the percentage of root dry weight in upper vs. lower halves of the rootball (sawtooth oak, cherrybark oak, black walnut, and baldcypress), and an increase in the percentage of primary lateral roots (lateral roots originating from taproots or roots functioning as taproots) on the upper (proximal) half of taproots (cherrybark oak, pecan, and baldcypress). Nutrients in leaves, stems, and roots of sawtooth oak seedlings were analyzed at both harvests. Seedlings grown in $\mathrm{Cu}(\mathrm{OH})_{2}$-treated containers had more $\mathrm{Cu}$ in most plant tissues than nontreated seedlings. Also, seedlings grown in $\mathrm{Cu}(\mathrm{OH})_{2}$-treated containers had higher total $\mathrm{Ca}$ and $\mathrm{Mg}$ concentrations at transplanting and higher total $\mathrm{N}$ and $\mathrm{Zn}$ concentrations at the end of the growing season than nontreated seedlings.
\end{abstract}

Many coarse-rooted tree genera, such as Quercus L., Juglans L., Carya Nutt., and Taxodium L., have ornamental, conservation, or reforestation value, but are found infrequently in landscapes because of difficulties

Received for publication 6 Nov. 1992. Accepted for publication 5 May 1993. Tennessee Technological Univ. (TTU) College of Agriculture and Home Economics manuscript no. 49. We thank W. Edgar Davis and Monica Wertz for their technical assistance. The use of trade names does not imply endorsement by us, TTU, Texas A\&M Univ., or The Ohio State Univ. of the products named, nor criticism of similar ones not mentioned. The cost of publishing this paper was defrayed in part by the payment of page charges. Under postal regulations, this paper therefore must be hereby marked advertisement solely to indicate this fact.

'Assistant Professor. Present address: Dept. of Horticultural Sciences, Texas A\&M Univ., College Station, TX 77843-2133.

${ }^{2}$ Associate Professor. concentrations and distribution is limited (Arnold and Struve, 1989a). Initial results with moderate [green ash (Fraxinus pennsylvanica Marsh.)] to very coarse-rooted species (baldcypress) indicate that $\mathrm{Cu}(\mathrm{OH})_{2}$ treated containers [either in a latex paint carrier or formulated as Spin Out (Griffin Corp., Valdosta, Ga.)] may substantially reduce, if not completely eliminate, circled, kinked, and matted roots at container wall-medium interfaces (Arnold, 1992; Beeson and Newton, 1992).

The objectives of this study were to test the effectiveness of $\mathrm{Cu}(\mathrm{OH})_{2}$-treated containers in altering root distribution and nutrient uptake patterns of selected coarse-rooted species during container production.

\section{Materials and Methods}

Stratified seeds of sawtooth oak, white oak, cherrybark oak, post oak, black walnut, pignut hickory, baldcypress (K \& S Jeane Seed, Quitman, La.), Chinese chestnut (Empire Chestnut Co., Carrollton, Ohio), and pecan (Sheffield's Seed Co., Locke, N. Y.) were sown in flats containing 3 milled pine bark: 1 sand medium $(\mathrm{v} / \mathrm{v})$ between 19 Feb. and 21 Mar. 1991. Flats were placed in a greenhouse (Cookeville, Term.) covered with 55\% lightexcluding material; day/night temperatures were set at $24 / 18 \mathrm{C}$. As the first true leaves began to expand between 8 Mar. and 9 Apr., 40 seedlings of each species were uprooted gently, the lower halves of taproots were removed, and the seedlings were planted in black polyethylene 3.2-liter containers (16.25 $\mathrm{cm}$ in diameter, $16 \mathrm{~cm}$ high) (Zarn, Reidsville, N. C.) containing a medium of 3 milled pine bark: 1 sand $(\mathrm{v} / \mathrm{v})$ supplemented with $3.5 \mathrm{~kg}$ dolomite $/ \mathrm{m}^{3}, 1.7 \mathrm{~kg}$ 0N-20P-0K, and Micromax (Sierra Chemical Co., Milpitas, Calif.). Before planting, the interior surfaces of half of the containers for each species were painted by hand with white interior latex paint containing $100 \mathrm{~g} \mathrm{Cu}(\mathrm{OH})_{2}$ (Griffin Corp.)/ liter. After planting, $16 \mathrm{~g} 18 \mathrm{~N}-3.1 \mathrm{P}-8.3 \mathrm{~K}-$ 1Fe Sierrablen Nursery Mix 8- to 9-month formulation (Sierra Chemical Co.) was applied to the surface of each container. The plants were returned to the greenhouse, and each species was placed in a randomized complete-block design of two blocks (adjacent benches) with 20 plants/block for each of the two container treatments (360 total plants).

From 2 to 6 May, half (10) of the seedlings of each species and container treatment combination was harvested to determine growth [height, stem diameter $(5 \mathrm{~cm}$ above the root collar)], foliage and stem dry (2 weeks at $70 \mathrm{C})$ weight, root distribution, and mineral nutrition characteristics. The rootballs of five seedlings of each species and treatment combination were dissected horizontally to determine root dry weight in the upper and lower halves of rootballs. A cylindrical ring of medium $(2.5$ and $4.0 \mathrm{~cm}$ wide for 3.2- and 15.0-liter containers, respectively) containing about onehalf of the volume of medium was removed from the other five seedlings of each species and treatment combination to determine the 
dry weight of roots contained in the inner and outer one-half volumes of the containers. The number of primary $(10$, lateral roots originating from the upper (proximal) and lower (distal) half of the taproot (or regenerated lateral roots assuming the form of a taproot) was recorded for each plant. After being rinsed in tap and distilled water and dried, foliage, stem, and root tissue samples of three sawtooth oak seedlings per container treatment were sent to the Research and Analytical Laboratory (Wooster, Ohio) for nutrient analysis.

On 7 May, the remaining one-half of the seedlings of each species and container treatment was transplanted from the nontreated and $\mathrm{Cu}(\mathrm{OH})_{2}$-treated 3.2-liter containers to nontreated and $\mathrm{Cu}(\mathrm{OH})_{2}$-treated black polyethylene 15 -liter containers $(28.5 \mathrm{~cm}$ in diameter, $23.5 \mathrm{~cm}$ high) (Zarn), respectively, and placed outdoors under 55\% light exclusion. The medium used was that described previously, except an additional $48 \mathrm{~g}$ of the $18 \mathrm{~N}-$ 3.1P-8.3K fertilizer was applied to the surface of each container. After 14 days of acclimation, the plants were moved to a graveled container yard, the same blocking design was maintained as in the greenhouse. Plants were irrigated daily by hand in the greenhouse and using overhead impact sprinklers outdoors. During the experiment, a $20 \mathrm{~N}-8.7 \mathrm{P}-16.7 \mathrm{~K}$ water-soluble fertilizer (Peters; W.R. Grace Co., Fogelsville, $\mathrm{Pa}$.) was applied weekly at a rate of $200 \mathrm{mg} \mathrm{N} /$ liter water.

Midday (between 12:00 and 3:00 PM) air temperatures adjacent to the southern side of the containers, medium temperatures adjacent to the interior south-facing container wall, and medium temperatures at $\approx 2.5 \mathrm{~cm}$ (in 3.2-liter containers) or $4 \mathrm{~cm}$ (in 15-liter containers) inside the south-facing container wall were sampled using an expanded-range digital thermometer with stainless-steel triple-purpose probes (Fisherbrand; Fisher Scientific, Pitts- burgh). Readings were taken at 1- to 3-day intervals from 22 Apr. through 27 Sept. 1991. The temperature probes were placed on two pots of sawtooth oak seedlings per container treatment. Probes adjacent to container walls were within 0.5 to $1.0 \mathrm{~cm}$ of the walls, but not in direct contact with them.

The second harvest occurred just before leaf abscission at the end of the growing season-1 8 Sept. for black walnut, pignut hickory, and pecan; 20 Sept. for post oak; 4 Oct. for Chinese chestnut; 17 Oct. for white oak; 23 Oct. for baldcypress; 1 Nov. for cherrybark oak; and 11 Nov. for sawtooth oak. Data were collected as described previously. In addition, root ratings were recorded for each plant. The following rating scale was used: $0=$ many matted, circled, and kinked roots present at the container wall-medium interface, 1 = several lateral roots elongating $>1 \mathrm{~cm}$ after contacting treated surfaces and taproot(s) deflected and continuing to elongate after contacting a container surface, 2 = no escaped lateral roots, but taproot(s) continuing to elongate more slowly after contacting a container surface, $3=$ no escaped lateral roots and taproot(s) ceasing to elongate after contacting a container surface.

Morphological and nutrient data for each species were analyzed separately using SAS's general linear models procedure (SAS Institute, 1985). Means were declared significantly different, where appropriate, using Fisher's least significant difference procedure $(P \leq$ $0.05)$.

\section{Results}

Growth in 3.2-liter containers. At the first harvest, sawtooth oak seedlings grown in $\mathrm{Cu}(\mathrm{OH})_{2}$-treated containers had significantly $(P \leq 0.05)$ increased height (46 vs. $34 \mathrm{~cm})$; stem diameter (3.7 vs. $3.3 \mathrm{~mm}$ ); foliage $(4.5$ vs. $3.3 \mathrm{~g}$ ), stem ( 2.2 vs. $1.5 \mathrm{~g}$ ), and root (1.9 vs.
$1.7 \mathrm{~g}$ ) dry weights; and total number of $1^{\circ}$ lateral roots (133 vs. 83) compared to those from nontreated containers. Treating containers also increased the height ( 26 vs. $22 \mathrm{~cm})$, stem diameter ( 2.0 vs. $1.7 \mathrm{~mm}$ ), and foliage dry weight ( 0.30 vs. $0.19 \mathrm{~g})$ of baldcypress seedlings. Cupric hydroxide-treated containers increased root dry weight (1.03 vs. $0.71 \mathrm{~g}$ ) and total number of $1^{\circ}$ lateral roots (168 vs. 98) on white oak seedlings, but only the total number of 10 lateral roots on cherrybark oak (110 vs. 81 ) and pecan (54 vs. 43 ).

Black walnut, Chinese chestnut, and pignut hickory seedlings grown in $\mathrm{Cu}(\mathrm{OH})_{2}-$ treated containers had a higher percentage of their root dry weight in the interior of the rootball than the nontreated seedlings: $77 \%$ vs. $57 \%, 95 \%$ vs. $80 \%$, and $95 \%$ vs. $88 \%$, respectively. No significant differences in root dryweight distribution between upper and lower halves of the container volumes were found at transplanting to the larger 15-liter containers (data not presented).

Second harvest growth. Overall, plant growth varied considerably among species. Many of the species with continuously flushing or recurrently flushing growth patterns grew taller rapidly: white oak $(121 \mathrm{~cm})$, cherrybark oak (134 cm), sawtooth oak (102 $\mathrm{cm})$, Chinese chestnut $(144 \mathrm{~cm})$, and baldcypress $(136 \mathrm{~cm})$. More moderate responses were observed in post oak $(57 \mathrm{~cm})$, black walnut $(64 \mathrm{~cm})$, and pecan $(43 \mathrm{~cm})$. Most pignut hickory seedlings failed to break bud after the initial growth flush $(15 \mathrm{~cm})$ following germination, with much of the first year's growth occurring in the root systems (9.8 $\mathrm{g}$ for roots vs. $1.7 \mathrm{~g}$ for shoots). All of the latter species, except post oak, exhibited a determinate shoot growth pattern during the experiment. A similar shoot growth pattern was observed previously with yellow buckeye (Aesculus flava Ait.) seedlings during con-

Table 1. Effects of $\mathrm{Cu}(\mathrm{OH})_{2}$-treated $(+)$ and nontreated $(-)$ 15-liter containers on growth and root distribution of seedlings of nine coarse-rooted species.

\begin{tabular}{|c|c|c|c|c|c|c|c|c|}
\hline \multirow[b]{3}{*}{ Species } & \multirow[b]{3}{*}{$\mathrm{Cu}(\mathrm{OH})_{2}$} & \multicolumn{2}{|c|}{ Root dry $w^{z}(\%)$} & & & & \multirow{3}{*}{$\begin{array}{c}1^{\circ} \text { Lateral }^{y} \\
\text { roots on the } \\
\text { upper half } \\
\text { of taproots }(\%)\end{array}$} & \multirow[b]{3}{*}{$\begin{array}{c}\text { Root } \\
\text { rating }\end{array}$} \\
\hline & & \multirow{2}{*}{$\begin{array}{c}\text { Inner } \\
\text { cores of } \\
\text { rootballs }\end{array}$} & \multirow{2}{*}{$\begin{array}{l}\text { Upper } \\
\text { half of } \\
\text { rootballs }\end{array}$} & \multicolumn{3}{|c|}{$1^{\circ}$ Lateral roots $^{y}$ (no.) } & & \\
\hline & & & & Per plant & $\begin{array}{l}\text { Upper half } \\
\text { of taproots }\end{array}$ & $\begin{array}{l}\text { Lower half } \\
\text { of taproots }\end{array}$ & & \\
\hline \multirow[t]{2}{*}{ Quercus acutissima } & - & 72 & $-\overline{31}$ & 209 & 52 & 157 & 26 & 0.0 \\
\hline & + & 85 & 43 & 212 & 59 & 153 & 30 & $2.1^{*}$ \\
\hline \multirow[t]{2}{*}{ Q.alba } & . & 90 & 66 & 184 & 61 & 123 & 35 & 0.0 \\
\hline & + & $96^{*}$ & 65 & 155 & 64 & 91 & 41 & $2.9^{*}$ \\
\hline \multirow[t]{2}{*}{$Q$. falcata } & - & 69 & 42 & 166 & 38 & 128 & 25 & 0.0 \\
\hline & + & 81 & $56^{*}$ & 161 & $67^{*}$ & 94 & $44^{*}$ & $2.8^{*}$ \\
\hline \multirow[t]{2}{*}{ Q. stellata } & - & 90 & 59 & 150 & 57 & 92 & 46 & 0.0 \\
\hline & + & 94 & 61 & 228 & $96^{*}$ & 132 & 47 & $2.4^{*}$ \\
\hline \multirow[t]{2}{*}{ Juglans nigra } & - & 87 & 37 & 84 & 21 & 63 & 30 & 0.0 \\
\hline & + & $94^{*}$ & $58^{*}$ & 67 & 24 & 44 & 38 & $2.6^{*}$ \\
\hline \multirow[t]{2}{*}{ Carya glabra } & - & 95 & 78 & 122 & 68 & 54 & 55 & 0.0 \\
\hline & + & 99 & 68 & $71^{*}$ & $39^{*}$ & $32^{*}$ & 57 & $2.7^{*}$ \\
\hline \multirow[t]{2}{*}{ C. llinoinensis } & - & 86 & 30 & 83 & 28 & 55 & 34 & 0.0 \\
\hline & + & 90 & 33 & $60^{*}$ & 27 & $33^{*}$ & $45^{*}$ & $1.6^{*}$ \\
\hline \multirow[t]{2}{*}{ Castanea mollissima } & - & 67 & 65 & 80 & 44 & 37 & 74 & 0.0 \\
\hline & + & $85^{x}$ & 73 & 92 & $67^{*}$ & 25 & 81 & $2.2^{*}$ \\
\hline \multirow[t]{2}{*}{ Taxodium distichum } & - & 74 & 27 & 159 & 30 & 129 & 20 & 0.0 \\
\hline & + & $83^{4}$ & $40^{*}$ & 133 & 47 & 83 & $36^{*}$ & $1.8^{*}$ \\
\hline
\end{tabular}

${ }^{z}$ Values are means of five observations.

y Values are means of 10 observations.

${ }^{x}$ Root ratings range from $0=$ many circled, matted, or kinked roots at the contaner wall-media interfacc to $3=$ no cscaped lateral roots and no elongation of taproots after contacting a container surface.

"Significant at $P \leq 0.05$ by Fisher's LSD. 
tainer production (unpublished data). Apparently some ecto- or endodormancy factor must be overcome before these species can be induced into recurrent flushing, even under environmental conditions favorable for shoot elongation.

Generally, $\mathrm{Cu}(\mathrm{OH})_{2}$-treated contained had little effect on seedling height, number of growth flushes, stem diameter, or total dryweight accumulation at the end of the season, except for baldcypress seedlings, which had a significantly greater stem diameter (27 vs. 24 $\mathrm{mm}$ ), and higher foliage (53.7 vs. $39.7 \mathrm{~g}$ ), stem (132.0 vs. $103.2 \mathrm{~g}$ ), and total plant (316.0 vs. $247.6 \mathrm{~g})$ dry weights than seedlings in nontreated containers. Root dry weights of cherrybark oak seedlings were reduced significantly ( 81 vs. $106 \mathrm{~g}$ ) by treated containers, resulting in a reduced root: shoot ratio ( 0.5 vs. 0.8 ); however, total plant dry weight was not affected ( $234 \mathrm{vs.} 239 \mathrm{~g}$ ). The total number of 10 lateral roots in both Carya species was reduced by $\mathrm{Cu}(\mathrm{OH})_{2}$. The number of 10 lateral roots of pignut hickory in the upper and lower half of the containers and of pecan in the lower half only was reduced (Table 1).

Cupric hydroxide altered the root distribution of most of the species during growth in the 15-liter containers. Cupric hydroxide-treated containers increased the percentage of root dry weights present in the inner core in white oak, black walnut, Chinese chestnut, and baldcypress (Table 1). Sawtooth oak, cherrybark oak, black walnut, and baldcypress seedlings grown in treated containers also had an increased percentage of root dry weights in the upper half of the rootball, a result that allowed a more even vertical distribution of the root systems (Table 1); i.e., closer to $50 \%$ of the root system in the upper and lower halves of the rootball. Cherrybark oak, post oak, and Chinese chestnut seedlings grown in treated containers had more 10 lateral roots on the upper half of the taproots, pecan had fewer $1^{\circ}$ lateral roots on the lower half, and pignut hickory had fewer $1^{\circ}$ lateral roots on the upper and lower halves (Table 1). In $\mathrm{Cu}(\mathrm{OH})_{2}$-treated containers, cherrybark oak, pecan, and baldcypress seedlings had more $1^{\circ}$ lateral roots on the upper half of the taproots than seedlings in nontreated containers (Table 1).

Cupric hydroxide-treated containers significantly reduced circled, kinked, and matted roots formed at the container wall-medium interfaces in all species tested, but the relative effectiveness varied among species (Table 1). White oak and cherrybark oak roots contacting treated surfaces were nearly completely inhibited. Sawtooth oak, post oak, black walnut, pignut hickory, and Chinese chestnut roots were not inhibited as much; taproots elongated, but root deformation was less in $\mathrm{Cu}(\mathrm{OH})_{2}$-treated containers than in nontreated containers. This response was even more pronounced with pecan and baldcypress.

Nutrient status of sawtooth oak in 3.2-liter containers. Although statistical differences in tissue concentrations (data not presented) and total quantity (Table 2) of nutrients present in tissues were found between treatments, nutrient levels did not seem to be deficient for sawtooth oak seedlings from either treated or nontreated containers. On a total-quantityper-tissue basis, $\mathrm{Cu}(\mathrm{OH})_{2}$-treated containers did not reduce any nutrients, and foliar $\mathrm{Ca}$, $\mathrm{Mg}, \mathrm{Zn}$, and $\mathrm{Cu}$; stem $\mathrm{Ca}, \mathrm{Mg}, \mathrm{Fe}$, and $\mathrm{Zn}$; and root and total plant $\mathrm{Cu}$ significantly increased (Table 2).

End-of-season nutrient status of sawtooth oak. At the end of the growing season (November), the total quantity of root N, K, and $\mathrm{Cu}$ and whole-plant $\mathrm{Cu}$ of sawtooth oak seedlings in $\mathrm{Cu}(\mathrm{OH})_{2}$-treated containers were higher than those in nontreated containers (Table 2). The low quantities of some nutrients in foliar samples at the final sample date likely were due to nutrient translocation in response to autumn leaf senescence, which had begun.

Production temperatures. During the greenhouse and shade-acclimation phases, medium temperatures adjacent to exterior container surfaces at midday were similar to ambient air

Table 2. Total quantities (in milligrams) of selected nutrients in various tissues of Quercus acutissima grown in $\mathrm{Cu}(\mathrm{OH})_{2}$-treated containers.

\begin{tabular}{|c|c|c|c|c|c|c|}
\hline \multirow[b]{2}{*}{ Harvest } & \multirow[b]{2}{*}{ Nutrient } & \multirow[b]{2}{*}{$\mathrm{Cu}(\mathrm{OH})_{2}$} & \multicolumn{4}{|c|}{ Total nutrient quantity (mg) } \\
\hline & & & Foliage & Stem & Root & Plant \\
\hline \multirow[t]{24}{*}{$\overline{\text { May }}$} & $\mathrm{N}$ & - & 108 & 32.6 & 52.1 & 192.4 \\
\hline & & + & 173 & 41.5 & 49.2 & 263.9 \\
\hline & $\mathbf{P}$ & - & 9.0 & 3.8 & 7.7 & 20.6 \\
\hline & & + & $13.7^{*}$ & 6.3 & 7.5 & 27.5 \\
\hline & $\mathrm{K}$ & - & 38.9 & 16.0 & 20.7 & 75.6 \\
\hline & & + & $70.3^{*}$ & $27.8^{*}$ & 23.2 & 121.3 \\
\hline & $\mathrm{Ca}$ & - & 31.2 & 13.9 & 6.2 & 51.4 \\
\hline & & + & $58.2^{* *}$ & $27.7^{* *}$ & 8.0 & $93.9^{*}$ \\
\hline & Mg & - & 3.0 & 2.0 & 1.9 & 6.9 \\
\hline & & + & $5.1^{* *}$ & $3.9^{* *}$ & 2.3 & $11.3^{*}$ \\
\hline & $\mathrm{Mn}$ & - & 1.1 & 0.4 & 0.3 & 1.8 \\
\hline & & + & 1.9 & 0.7 & 0.3 & 3.0 \\
\hline & $\mathrm{Fe}$ & - & 0.4 & 0.1 & 0.3 & 0.8 \\
\hline & & + & 0.6 & $0.2^{* *}$ & 0.3 & 1.1 \\
\hline & B & - & 0.4 & 0.1 & 0.1 & 0.6 \\
\hline & & + & 0.7 & $0.2^{*}$ & 0.1 & 1.0 \\
\hline & $\mathbf{Z n}$ & - & 0.1 & 0.06 & 0.2 & 0.4 \\
\hline & & + & $0.2^{* *}$ & $0.11^{* *}$ & 0.3 & 0.6 \\
\hline & $\mathrm{Cu}$ & - & 0.03 & 0.02 & 0.03 & 0.1 \\
\hline & & + & $0.06^{* *}$ & $0.04^{*}$ & $0.19^{* *}$ & $0.3^{* *}$ \\
\hline & Al & - & 0.1 & 0.0 & 0.4 & 0.5 \\
\hline & & + & 0.1 & 0.1 & 0.4 & 0.6 \\
\hline & $\mathrm{Na}$ & - & 0.6 & 0.4 & 1.5 & 2.4 \\
\hline & & + & 0.4 & 0.4 & 1.7 & 2.5 \\
\hline \multirow[t]{24}{*}{ November } & $\mathbf{N}$ & - & 811 & 558 & 1141 & 25,100 \\
\hline & & + & 795 & $1175^{*}$ & $1966^{* *}$ & $39,400^{*}$ \\
\hline & $\mathbf{P}$ & - & 83.6 & 65 & 184 & 331 \\
\hline & & + & 77.1 & 154 & $293^{\circ}$ & 524 \\
\hline & K & - & 427 & 344 & 856 & 1627 \\
\hline & & + & 386 & 633 & $1317^{* *}$ & 2336 \\
\hline & $\mathrm{Ca}$ & - & 404 & 644 & 384 & 1433 \\
\hline & & + & 599 & 1295 & 804 & 2698 \\
\hline & Mg & - & 28.1 & 89 & 99 & 215 \\
\hline & & + & 39.7 & 177 & 137 & 354 \\
\hline & Mn & - & 5.0 & 7.7 & 4.6 & 17.4 \\
\hline & & + & 9.2 & 21.7 & 8.2 & 39.2 \\
\hline & $\mathrm{Fe}$ & - & 1.6 & 2.5 & 16.4 & 20.5 \\
\hline & & + & 2.4 & 6.1 & 23.6 & 32.2 \\
\hline & B & - & 1.4 & 1.2 & .1 .1 & 3.7 \\
\hline & & + & 2.3 & 2.3 & 1.7 & 6.3 \\
\hline & $\mathrm{Zn}$ & - & 1.3 & 2.2 & 4.3 & 7.8 \\
\hline & & + & 2.8 & 7.0 & 9.7 & $19.5^{*}$ \\
\hline & $\mathrm{Cu}$ & - & 0.2 & 0.5 & 1.7 & 2.5 \\
\hline & & + & 0.3 & $1.1^{*}$ & $65.6^{* *}$ & $71.0^{* *}$ \\
\hline & $\mathrm{Al}$ & - & 1.3 & 1.0 & 15.0 & 17.3 \\
\hline & & + & 2.3 & $2.4^{*}$ & 31.4 & 36.2 \\
\hline & $\mathrm{Na}$ & - & 5.7 & 3.7 & 31.1 & 40.5 \\
\hline & & + & 8.3 & 6.4 & 43.2 & 57.9 \\
\hline
\end{tabular}

***significant at $P \leq 0.10$ or 0.05 , respectively, by Fisher's LSD; values are means of three observations. temperatures, while interior medium temperatures were slightly lower (Fig. 1). After moving containers to the outdoor container yard, midday temperatures in the medium adjacent to the exterior container surfaces were 3 to $5 \mathrm{C}$ higher than those in the interior of the medium and 1 to $3 \mathrm{C}$ higher than ambient through September (Fig. 1).

\section{Discussion}

Cupric hydroxide-treated containers did not adversely affect dry-matter accumulation, shoot elongation, or stem diameter in any species, except for a transitory reduction in the root dry weight and stem diameter of white oak after being transplanted to 15-liter containers, and reduced first-year dry weight of root systems of cherrybark oak, an effect resulting in a lower root: shoot dry weight ratio at the end of the growing season. However, by 


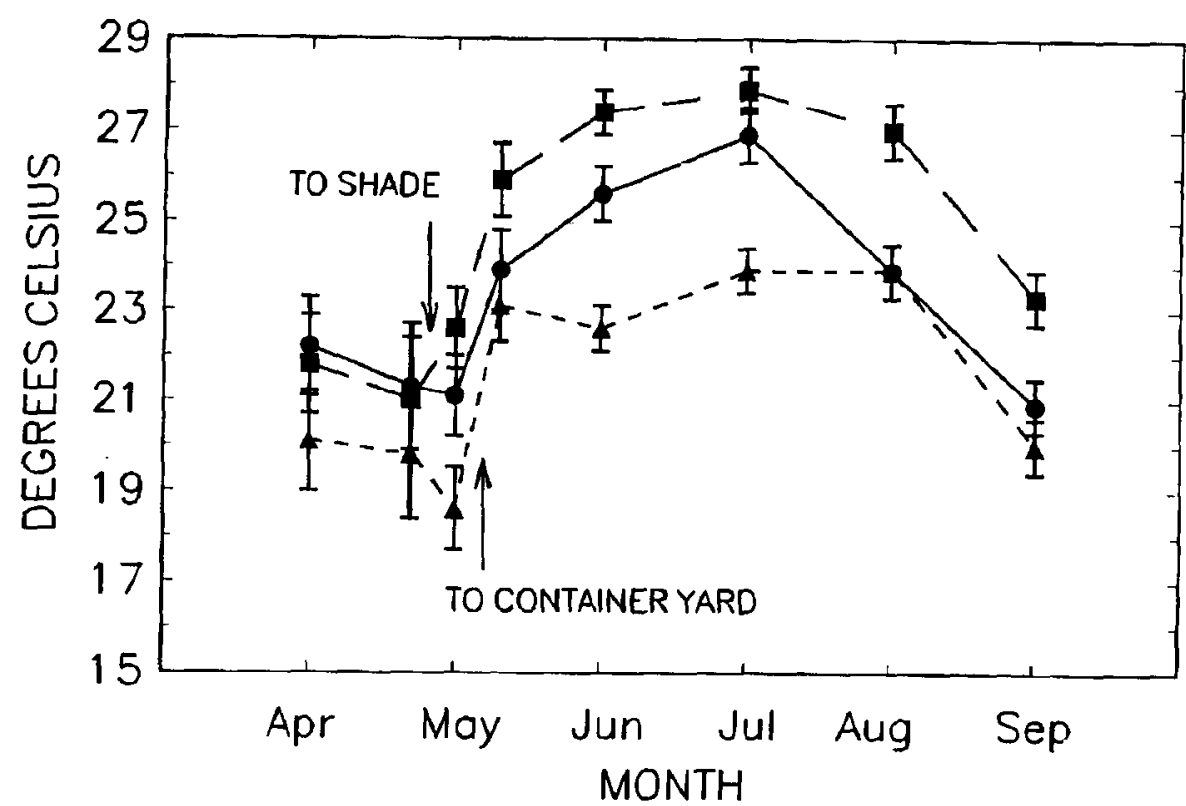

Fig. 1. Air and medium temperatures during greenhouse (April to May), shade-acclimation (May), and container-yard (May to September) phases of container production of Quercus acutissima seedlings. Ambient air temperatures adjacent to the southern container wall $(\odot)$, medium temperature adjacent to the southern side of the container ( $\square$ ), and interior medium temperatures ( $\Delta$ ). Values are means $\pm s E$ of 15 to 56 observations.

the growing season's end, total plant dry weight and stem diameter were not affected in white oak or cherrybark oak. Similar reductions in the root: shoot ratio without reductions in total plant dry weight in response to $\mathrm{Cu}(\mathrm{OH})_{2}$ treated containers have been reported for woody (Arnold and Strove, 1989b) and herbaceous species (Case and Arnold, 1992). Early in the season, $\mathrm{Cu}$-treated containers induced increases in shoot growth of sawtooth oak and baldcypress seedlings, but, by the end of the growing season, only baldcypress seedlings showed significantly improved shoot growth in response to $\mathrm{Cu}(\mathrm{OH})_{2}$-treated containers. The increased shoot growth of baldcypress in response to $\mathrm{Cu}(\mathrm{OH})_{2}$-treated containers confirms earlier reports by Arnold (1992) and Beeson and Newton (1992).

Previous experiments using $\mathrm{CuCO}_{3}$ - and $\mathrm{Cu}(\mathrm{OH})_{2}$-treated containers showed nearly complete control of circled, kinked, and matted roots formed at container wall-medium interfaces with fibrous-rooted to moderately coarse-rooted landscape trees, such as northern red oak (Q. rubra L.), green ash, and apple (Malus $\times$ domestica Borkh.) (Arnold and Struve, 1989a, 1989b; Arnold and Young, 1991). While all of the coarse-rooted species in this study showed significantly reduced circled, kinked, and matted roots in response to $\mathrm{Cu}(\mathrm{OH})_{2}$-treated containers, control with most species was not complete (Table 1). Beeson and Newton (1992) also found incomplete control of deflected roots on some species, including baldcypress, using $\mathrm{Cu}(\mathrm{OH})_{2}$ treated containers. Results of previous experiments (Arnold, 1992) on baldcypress with $\mathrm{Cu}(\mathrm{OH})_{2}$-treated pyramid pots (round containers with stepped-pyramid indentations) suggest that further study is needed to determine if combining mechanical impedance with chemical treatments, such as $\mathrm{Cu}(\mathrm{OH})_{2}$, can improve control of container-induced root deformation.

Cupric hydroxide significantly altered the horizontal root distribution of black walnut, pignut hickory, and Chinese chestnut grown in 3.2-liter containers and of white oak, black walnut, Chinese chestnut, and baldcypress grown in 15-liter containers (Table 1). Of the species affected, $\mathrm{Cu}(\mathrm{OH})_{2}$-treated containers caused a $6 \%$ to $20 \%$ shift in the partitioning of root dry weight from the exterior to interior half of the rootballs (Table 1). Most of this shift likely was due to reduced root matting at the container wall-medium interface on treated seedlings. Root-zone temperatures of $>32$ to 40C, depending on species and environment, have been shown to be detrimental to plant growth or photosynthesis (Foster et al., 1991; Johnson and Ingram, 1984; Ruter and Ingram, 1992). Root-zone temperatures measured in this study did not reach these levels (Fig. 1). However, temperatures indicated that roots in the interior portions of the rootballs were subjected to lower midday temperatures than those found near the container walls. Thus, in container production environments where supraoptimal root-zone temperatures are encountered, $\mathrm{Cu}(\mathrm{OH})_{2}$-treated containers may reduce the percentage of the root system subjected to these extreme temperatures and subsequently reduce the adverse effects on plant growth.

By the end of the season, $\mathrm{Cu}(\mathrm{OH})_{2}$-treated containers caused a $10 \%$ to $21 \%$ shift in dryweight accumulation from the bottom to top half of the rootball in sawtooth oak, cherrybark oak, black walnut, and baldcypress seedlings, and increased the percentage of 10 lateral roots initiated on the top portion of cherrybark oak, pecan, and baldcypress taproots (Table 1).
The shift in dry-matter allocation was due to reduced growth of the taproots after they contacted the bottom of the containers and the subsequent more-even vertical distribution of the root system.

The net effect of the $\mathrm{Cu}(\mathrm{OH})_{2}$-treated containers was to increase the total numberof 10 lateral roots on sawtooth oak, white oak, cherrybark oak, and pecan growing in 3.2-liter containers and to decrease the total number of 10 laterals on pignut hickory and pecan growing in 15-liter containers (Table 1). The greater number of $1^{\circ}$ laterals on pecan may have little importance to transplant survival, since many of these 10 lateral roots were located on the lower portion of the taproots (Table 1), which continued to elongate after deflection at the bottom of the container and should be removed at transplanting. Likewise, a portion of the increase in the number of 10 lateral roots on nontreated pignut hickory seedlings was due to continued growth of the taproot after contactiug the bottom of the container. A similar proliferation of 10 lateral roots on the portion of taproots deflected by the bottom of containers often was observed for the seedlings of most species in nontreated containers. If these plants were root-pruned correctly before being transplanted (Harris, 1992; Stone and Norberg, 1978), many of these $1^{\circ}$ lateral roots would be lost. Root-pruning green ash and apple seedlings grown in $\mathrm{CuCO}_{3}$-treated and nontreated containers to correct root deformation (Harris, 1992; Stone and Norberg, 1978) has shown that plants grown in $\mathrm{CuCO}_{3}$-treated containers lost less of the lateral root system (Arnold and Young, 1991). Also, the number of 10 lateral roots $>1 \mathrm{~mm}$ in diameter is an important indicator of initial field performance of bare-root seedlings of northern red oak (Ruehle and Kormanik, 1986) and sweetgum (Liquidambar styraciflua L.) (Kormanik, 1986). No distinction was made in this study in $1^{\circ}$ lateral root size, but the data suggest that further studies are needed on the effects of copper-treated containers and root-pruning practices on transplant establishment and $1^{\circ}$ lateral root development in container-grown plants.

The increased amount of $\mathrm{Cu}$ in tissues (Table2), particularly roots, of seedlings grown in $\mathrm{Cu}(\mathrm{OH})_{2}$-treated containers confirms earlier reports on $\mathrm{Cu}$ accumulation in $\mathrm{CuCO}_{3}$ treated green ash (Arnold and Strove, 1989a) and $\mathrm{Cu}(\mathrm{OH})_{2}$-treated double-file viburnum (Viburnum tomentosum Thunb. var. plicatum) (Flanagan and Witte, 1991). By the end of the season, no nutrient concentrations or total quantities (Table 2) in any plant tissue were decreased by $\mathrm{Cu}(\mathrm{OH})_{2}$-treated containers. In fact, treated containers significantly $(P \leq 0.05)$ increased the total quantity of root $\mathrm{N}, \mathrm{K}$, and $\mathrm{Cu}$ and whole-plant $\mathrm{Cu}$ (Table 2). An accelerated autumnal translocation of nutrients from senescing foliage of $\mathrm{Cu}(\mathrm{OH})_{2}$-treated seedlings compared to nontreated seedlings was unlikely, as the total quantities of nutrients in the foliage tissues did not differ significantly between treatments (Table 2). Perhaps the more fibrous and evenly distributed root systems of plants grown in $\mathrm{Cu}(\mathrm{OH})_{2}$-treated 
containers allowed a greater uptake of available nutrients from the container medium and, thus, improved the plants' nutrient-use efficiency.

The increased quantity of $\mathrm{N}$ is of particular interest, as this nutrient is most likely to be limiting after seedlings are transplanted to the landscape. Increased growth of trees grown in $\mathrm{CuCO}_{3}$-treated containers over those from nontreated containers, particularly in the year after transplanting to the field, have been reported (Arnold and Struve, 1989b). Additional study is needed to determine if higher stored nutrient reserves in the stem and root tissues of trees grown in $\mathrm{Cu}$-treated containers might be translocated to accelerate growth the following spring.

This study demonstrated that $\mathrm{Cu}(\mathrm{OH})_{2}$ treated containers reduced the amount of circled, kinked, and matted roots that developed during the production of several coarserooted species. It was also shown that, for some species, $\mathrm{Cu}(\mathrm{OH})_{2}$-treated containers altered dry-matter partitioning of the root systems from exterior to interior portions of the rootballs, induced a more equal partitioning between upper and lowerhalves of the rootball, or both. Cupric hydroxide-treated containers also increased the total quantity of several nutrients in various plant tissues.

\section{Literature Cited}

Arnold, M.A. 1992. Timing, acclimation period, and cupric hydroxide concentration after growth responses of the Ohio production system. J. Environ. Hort. 10:114-117.

Arnold, M.A. and D.K. Struve. 1989a. Cupric carbonate controls green ash root morphology and root growth. HortScience 24:262-264.

Arnold, M.A. and D.K. Strove. 1989b. Growing green ash and redoak in $\mathrm{CuCO}_{3}$-treated containers increases root regeneration and shoot growth following transplant. J. Amer. Soc. Hort. Sci. 114:402-406.

Arnold, M.A. and E. Young. 1991. $\mathrm{CuCO}_{3}$-painted containers and root pruning affect apple and green ash root growth and cytokinin levels. HortScience 26:242-244.

Beeson, R.C. and R. Newton. 1992. Shoot and root responses of eighteen southeastern woody landscape species in cupric hydroxide-treated containers. J. Environ. Hort. 10:214-217.

Case, G.N. and M.A. Arnold. 1992. Cupric hydroxide-treated containers decrease pot-binding of five species of vigorously rooted greenhouse crops. Proc. Southern Nurserymen's Assn. Res. Conf. 37:94-98.

Dirr, M.A. 1990. Manual of woody landscape plants: Their identification, ornamental characteristics, culture, propagation and uses. Stipes Publishing Co., Champaign, Ill.

Flanagan, P.C. and W.T. Witte. 1991. Effects of chemical root pruning on root regeneration and cellular structure of viburnum root tips. Proc.
Southern Nurserymen's Assn. Res. Conf. 36:4649.

Foster, W.J., D.L. Ingram, and T.A. Nell. 1991 Photosynthesis and root respiration in Ilex crenata 'Rotundifolia' at supraoptimal root-zone temperatures. HortScience 26:535-537.

Harris, R.W. 1992. Arboriculture: Integrated management of landscape trees, shrubs, and vines. Prentice-Hall, Englewood Cliffs, N.J. p. 674.

Jaynes, R.A. (ed.). 1979. Nut tree culture in North America. Northern Nut Growers Assn., Hamden, Conn. p. 466.

Johnson, C.R. and D.L. Ingram. 1984. Pittosporum tobira response to container medium temperature. HortScience 19:524-525.

Kormanik, P.P. 1986. Lateral root morphology as an expression of sweetgum seedling quality. For. Sci. 32:595-604.

Ruehle, J.L. and P.P. Kormanik. 1986. Lateral root morphology: A potential indicator of seedling quality in northern red oak. U.S. Dept. of Agr., For. Serv., Southeastern Expt. Sta. Res. Note SE-344. p. 6.

Ruter, J.M. and D.L. Ingram. 1992. High root-zone temperatures influence $\mathrm{RuBisCO}$ activity and pigment accumulation in leaves of 'Rotundifolia' holly. J. Amer. Soc. Hort. Sci. 117:154-157.

SAS Institute. 1985. SAS user's guide: Statistics. version 5. SAS Institute, Cary, N.C. p. 956.

Stone, E.C. and E.A. Norberg. 1978. Containerinduced root malformation and its elimination prior to planting. Proc. Root Form of Planted Trees Symp., B.C. Ministry For., Canadian For. Serv. p. $65-72$. 